\title{
CULTURAL IDENTITY, CAPITALIZATION OF EDUCATION, AND PEDAGOGY FOR LIBERATION
}

\author{
Nanang Hasan Susanto \\ IAIN Pekalongan \\ E-mail: nananghasansusanto@iainpekalongan.ac.id \\ Ulfah Nabila \\ IAIN Pekalongan \\ E-mail: ulfanabila45@gmail.com \\ Muasomah \\ IAIN Pekalongan \\ E-mail: muasomah@iainpekalongan.ac.id
}

\begin{abstract}
This paper aims to unravel the impact of globalization, which bring the ideology of materialistic which erodes the cultural identity of third world countries, especially Indonesia, and gave birth to the capitalization of education. The data were collected through a qualitative approach, from the search of various kinds of literature on critical education and the reality of national education, then analyzed using discourse analysis and cultural analysis. This paper argues that requires the hard work of educational institutions to transmit pedagogy for liberation Freire's concept, to unravel the problems of the national education world. Through educational principles that include students who are expected to have the awareness to take the necessary values to strengthen cultural identity, even loss of identity. Besides, the principle of pedagogy of liberation is also expected to change the face of rigid, mechanistic education, too busy with textbooks and curriculum that are not in touch with social reality, so that through education can be expected to develop all potential and creativity of learners.
\end{abstract}

Abstrak: Tulisan ini bertujuan untuk membongkar dampak globalisasi yang membawa budaya positifistik materialistik Barat, serta mengikis identitas budaya Negara dunia ketiga khususnya Indonesia, serta melahirkan kapitalisasi pendidikan. Melalui pendekatan kualitatif, data dihimpun dari penelusuran berbagai literatur mengenai pendidikan kritis dan realitas pendidikan nasional, kemudian dianalisis menggunakan analisis wacana dan analisis budaya. Tulisan ini mengajukan gagasan, bahwa diperlukan kerja keras dari lembaga pendidikan untuk mentransmisikan konsep pendidikan membebaskan Freire, untuk mengurai berbagai problem dunia pendidikan nasional. Melalui prinsip pendidikan yang membebaskan, siswa diharapkan memiliki kesadaran kritis untuk mengambi lniai-nilai yang diperlukan dalam rangka memperkuat identitas 


\section{Nanang Hasan Susanto dkk, Cultural Identity}

budaya, bukannya malah kehilangan identitas dan jatidiri. Selain itu, prinsip pendidikan membebaskan juga diharapkan mampu mengubah wajah pendidikan yang kaku, mekanistik, terlalu disibukkan dengan buku ajar dan kurikulum yang tidak bersentuhan dengan realitas sosial, sehingga melalui pendidikan membebaskan diharapkan dapat mengembangkan segala potensi dan kreativitas peserta didik.

Keywords: globalization; cultural identity; capitalization of education; pedagogy for liberation

\section{INTRODUCTION}

Some experts say that education is one of the center poles that can increase the degree and dignity of a nation besides health ${ }^{1}$. In contrast to limited Natural Resources (SDA), Human Resources (HR) is something that is not limited. Here is where education plays an important role; if it is developed, it can grow to unlimited human ideas and creativity. At the level of reality, we see many developed and respected countries because of their success in developing ideas and creativity in their people. On the other hand, many countries have abundant natural resources, but they are difficult to move from their status as developing countries, because of the limited ideas and creativity of their people.

To develop limited ideas and creativity, Indonesian must be able to get out of the shadow of a superpower. It is because globalization, which, according to Sztompka, is defined as a process that produces a single world ${ }^{2}$, in the end, it shows the exploitation from strong countries to weak (backward) countries. According to Ian Roxborough, the exploitation process here is characterized by the unequal change process ${ }^{3}$. Also, the process of globalization, which Mansour Fakih calls a strong state effort to continue colonialism and developmentalism ${ }^{4}$, ultimately has an impact on the erosion of the typical Eastern metaphysical

1 See for example Raihani said that almost all major civilizations in the past always paid more attention to aspects of education than other aspects. Sunhaji, "Between Social Humanism And Social Mobilization: The Dual Role of Madrasah in the Landscape of Indonesian Islamic Education,” Journal Of Indonesian Islam 11, no. 1 (2017): 125-44.

2 Piotr Sztompka, Sosiologi Perubahan Sosial. Trans. Alimandan form "The Sociology of Social Change" (Jakarta: Prenada, 2004):101-102.

3 The unbalanced exchange that Roxborough means is arbitrary exploitation of Natural Resources from a strong country to a weak country, to produce materials that are supplied to a weak country, and make the country's people dependent on it. See:Ian Roxborough, Teori-teori Keterbelakangan (Jakarta: LP3ES, 1986): 70-71.

${ }^{4}$ Mansour Fakih, Runtuhnya Teori Pembangunan dan Globalisasi (Yogyakarta: Pustaka Pelajar, 2002): 211. 
guidelines ${ }^{5}$. Therefore, it is necessary to strengthen cultural identity to get out of the process which Gramsci calls hegemony ${ }^{6}$.

In this connection, Brameld quoted by Ki Supriyoko stated that there is a close relationship between education and culture concerning value development? Edward B. Tylor added that the culture has three strategic components, namely as an order, a process, and a certain vision (goals), then education is a cultural process. Therefore, there is no educational process without culture and vice versa. Thus, education and culture have a reciprocal relationship. In other words, it can be said that education is a variable that encourages cultural changes in an asymmetrical relationship system where one variable affects other variables (causal asymmetrical relationship).

Based on the background, the problem formulations discussed in this paper are, first, what is the influence of globalization on Indonesia's cultural identity. Second, it is how to form cultural identity and capitalization of education. Third, how the concept of Freire's pedagogy for liberation and its correlation with the capitalization of education. From the formulation of these problems, this paper aims to examine one of the major problems in the world of education in developing countries, especially Indonesia, related to globalization, the formation of cultural identities, and the capitalization of education. This paper also proposes the concept of Freire's pedagogy for liberation as an analysis to unravel these educational problems.

\section{Globalization and Cultural Identity}

Although its existence is inevitable ${ }^{8}$, globalization continues to be a topic of discussion and concern for experts. Globalization is not something new. Because since the past, globalization is a condition that is commonly faced by the world community. It is as stated by Sahlins that every society on this earth is a "global society" which changes according to the times. The times that are so fast are marked by technological advances, especially information technology, which further erases the distances of space and time in contemporary society. In

5 See: Clifford Geertz, Politik Kebudayaan (Yogyakarta: Kanisius, 1992).

6 Yasraf Amir Piliang, Kode, Gaya dan Matinya Makna : Semiotika dan Hipersemiotika (Bandung: Matahari, 2010): 71-73.

7 Ki Supriyoko, "Sistem Pendidikan Nasional dan Peran Budaya Dalam Pembangunan Berkelanjutan” (Seminar Pembangunan Hukum Nasional VIII, Denpasar, 2003).

8 Nanang Hasan Susanto, "Infiltrasi Globalisasi Terhadap Identitas Budaya dan Pendidikan Karakter Negara Berkembang," Lembaran Ilmu Kependidikan 47, no. 2 (2018): 57-66.

9 Marshall Sahlins, Goodbye to Tristes Tropique: Ethnography in the Context of Modern World History, dalam R.Borofsky, (ed.) Assessing Cultural Anthropology (New York: McGrawHill Inc, 1994):387. 
the context of education and the formation of cultural identities, advances in information technology pose a threat in itself.

Based on Kemoni's opinion quoted by Suneki, globalization in its natural form is capable of elevating culture and its values. ${ }^{10}$ Especially if in the process, each nation can strengthen its own culture and maintain the structure of their cultural values so that they are not lost and replaced by foreign cultures. Because in essence, globalization is a process of homogenization. ${ }^{11}$ It is consistent with what Parrot said, which defines globalization as a result of the accumulation or merger of internationalization ${ }^{12}$ and homogenization. ${ }^{13}$

Thus, through information technology facilities, each community can easily introduce their respective cultures to other communities. However, if a society does not strengthen its cultural identity, globalization can reduce self-confidence, even love for its own culture.

Cultural identity itself is part of the National identity of the Indonesian nation, as a form of creativity created by the nation's sons throughout Indonesia, in the framework of unity and integrity. Cultural identity can be a tool to foster a sense of pride for all Indonesians. Its existence can also be the identity and character of has which differentiates it from other nations. Cultural identity can be a means of unifying a nation, differentiating it from other nations, the foundation of the state, as well as state identity.

The importance of the existence of cultural identity makes resilience against globalization attacks a necessity. Globalization has a strong potential to weaken the culture of developing countries from the influence of strong State culture. With a tone of cynicism and suspicion of the hegemony of a strong State, Edward Said said that through the discourse of imperialism and colonialism, the identity of eastern countries is a form of construction made by western countries. Thus, almost no cultural identity remains in eastern countries. In more detail, Said analogizes the East as a theatre stage that is established in front of the West. Here, the West positions itself as an audience as well as a director who determines the storyline, even the costumes worn by the drama actors. Thus, there is almost no chance for the East to escape from the scenario created by the West. ${ }^{14}$

Said's prediction about the impact of neo-imperialism through the discourse of globalization can be seen with the fading of the cultural identity of developing

${ }^{10}$ Sri Suneki, "Dampak Globalisasi terhadap Eksistensi Budaya Daerah," Jurnal Ilmiah CIVIS 2, no. 1 (2012):314.

${ }^{11}$ Homogenization is the process of equating various parts of culture between nations.

${ }^{12}$ Internationalization is the spread of global understandings throughout the world and influencing one another.

${ }^{13}$ Etienne Perrot, The General Dimension of Globalization and Its Critics: The Ambiguitas of Globalization dalam Concilium (London: SCM Press, 2001):17.

${ }^{14}$ Edward Said, Orientalisme (Bandung: Pustaka, 1994): 39-64. 
countries under the pressure of strong State hegemony. In the Indonesian context, this can be seen from the fading of the noble values that were once upheld, such as manners, respect, hospitality, cooperation, and so on.

Besides, globalization that has brought secularism and materialism has also degraded the role of religion, eroded regional languages, $\mathrm{m}$ arginalized regional culture, and decreased self-confidence. The elements that form national identity include religion, ethnicity, culture, and language. The various elements are the bonds that glue Indonesia's unity, equality of fate, and the desire for independence, as well as achieving social welfare as a common goal.

Apart from strengthening the national identity, one of the main principles in democracy itself is freedom. In the context of strengthening cultural identity, this freedom can be used to present the culture of the people themselves as widely as possible to the international community. As stated by Koentjaraningrat, Indonesia does have not only diversity but also wisdom and ethical values. ${ }^{15} \mathrm{~A}$ similar view was conveyed by Heddy Shri Ahimsa Putra, who said that Indonesia's cultural diversity contains cultural values that serve as guidelines for Indonesian people to behave. ${ }^{16}$ It is where the points should be campaigned for by all the nation's children to have confidence in their own culture, then campaign for that culture to the entire world community.

On one occasion, Safril said that it does not cost a lot to make local Indonesian culture metamorphose into a global culture embraced by the world community. ${ }^{17}$ Showing local culture in the stage of international interactions does not require a large amount of money. It can be done through the use of information technology, such as social media, popular media, television, radio, newspapers, and other media. In the process of interacting with other cultures through these media, we will indeed get acquainted with different cultures, but self-confidence, as well as the strengthening of one's own cultural identity, will make interactions with other cultures enriching and strengthening our own cultural identity.

Therefore, in facing the flow of globalization, to have a positive impact, efforts are needed to pass on culture to the younger generation, so that people, especially the successors of this nation, know and understand their own culture so that they can face the flow of globalization appropriately. Cultural inheritance in the face of globalization can be done through education.

${ }^{15}$ Koentjaraningrat, Manusia dan Kebudayaan di Indonesia (Jakarta: Djambatan, 1983): x.

${ }^{16}$ Heddy Shri Ahimsa Putra, "Kebhinnekaan Budaya sebagai Modal Merespons Globalisasi," LITERASI: Indonesian Journal of Humanities 4, no. 2 (2015): 173.

${ }^{17}$ A. Safril Mubah, "Strategi Meningkatkan Daya Tahan Budaya Lokal dalam Menghadapi Arus Globalisasi,” Jurnal Unair 24, no. 4 (2011): 305. 
The use of educational instruments to inherit this culture is as done by Canadians. Sudarsana said that native Canadians could live in modern life with their cultural context and dominant culture because they carry out a process of cultural preservation by learning. ${ }^{18}$ Therefore it is necessary to have the role of educational institutions capable of realizing the cultural identity of a nation towards pedagogy for liberation. It can be done through development and education by prioritizing local cultural wisdom.

\section{Materialism, Rationalism and Cultural Identity}

Globalization which goes hand in hand with modernization, has brought a big wave of positivistic-materialistic ideology, where its impact can be felt in almost all nation-states in the world. Materialism itself is an understanding that believes that the most essential of all reality or all things is a matter. Thus, this understanding does not believe in or rule out anything that is nonmaterial. This understanding thrives in countries that have a capitalist economic system. In a cultural context, this understanding will measure a person's success based on the material he has. ${ }^{19}$

The concept of materialism which was strongly exhaled after the renaissance in western countries, went hand in hand with rationalism. Rationalism measures everything based on reason. Everything can only be accepted by society if it makes sense. However, in its development, this understanding of rationality was criticized by figures such as Michel Foucault, Jacques Derrida, Thomas Kuhn, and Paul Feyerabend by saying that the claims of Western truth cannot be forced as a universal truth, especially when dealing with local wisdom. ${ }^{20}$

Adian also criticized rationalism, who said that the concept of Habermas rational communication which was taken from the philosophy of Western nations could not be done by uprooting the cultural identities of nations in different worlds. Therefore, Adian conveyed the idea to reconcile the understanding of rationality with the cultural identity of each region, especially in multicultural societies. $^{21}$

Affiliation between one culture and another is something that cannot be avoided in the climate of globalization. Therefore, it is not necessary to avoid

${ }^{18}$ I. Ketut Sudarsana, "The thoughts of educational figures in Lifelong Learning:Policies, Practices, and Programs (Perspektif Peningkatan Mutu Pendidikan di Indonesia)," Jurnal Penjaminan Mutu 2, no. 2 (2016). Hal 49.

${ }^{19}$ Eko Rujito, "Boneka Barbie: antara Etos Kemandirian dan Budaya Materialisme," Majalah Ilmiah Pembelajaran 8, no. 2:x.

${ }^{20}$ George Levine, "Speaking for the Humanities," American Council of Learned Societies Occasional Paper, no. 7 (1989): 45.

${ }^{21}$ Donny Gahral Adian, "Reasoning in A Multicultural Society," Wacana 13, no. 2 (2011): 360. 
materialism and rationalism that came from Western culture, but also not to be taken out of the blue. This good attitude towards Western culture will strengthen our cultural identity if we respond to it well. It is as stated by Hall, who divides cultural identity into essentialists and non-essentialists. In contrast to essentialist cultural identities which reject external cultural influences to maintain their cultural identities, non-essentialist cultural identities regard culture as an unfinished product. It is always in the process of formation and is formed in a representation. Non-essentialist cultural identity makes culture something that never stops in the process of its formation so that it continues to change in the process. ${ }^{22}$

According to Suradi, this cultural change occurs because of cultural contact between countries which is interpreted as a dialectic of new values with old values that dominate one another, which allows homogenization and neo-liberalization in all aspects of life including local cultural values that have been become a community guideline. This condition leads to a change in values because society places more value on modern values by ignoring transcendental values. ${ }^{23}$

In the context of Indonesia, which is known as a religious nation, the notions of materialism and rationalism should not uproot our cultural identity, leaving cosmological values that believe in the existence of a transcendental dimension. Even so, in globalization, it is impossible to reject the understanding of materialism and rationalism completely. It is where the importance of the affiliation between Western understanding and our cultural identity, as stated by Adian and Hall so that cultural identity will be formed that continues to grow and strengthen over time.

\section{Materialism and Capitalization of Education}

The globalized infiltration of the state is strong in certain contexts weakening the cultural identity of our society. Western materialistic culture often creates a dichotomy in educational institutions, between children who have high social status and children who have low social status. Itis as stated by Darmaningtyas that currently, educational institutions have become an exclusive knowledge market for children with high social status, while children with low social status are only able to get an education at a private educational institution with mediocre quality and education costs. are borne in full, so that the impact on educational outcomes is not evenly distributed. ${ }^{24}$

22 Stuart Hall, "Cultural Identity and Cinematic Representation," Framework: The Journal of Cinema and Media 36 (1989): 68-81.

${ }^{23}$ AhmadSuradi,. "The Challenges of Ed u cation Based on Multicultural in National Local Culture Conservation in Globalization Era." Cendekia: Jurnal Kependidikan Dan Kemasyarakatan 16, no. 1 (2018).

${ }^{24}$ Darmaningtyas, Pendidikan Rusak-Rusakan (Yogyakarta: LkiS, 2009): 326. 
Raihani also conveyed the existence of discrimination in educational institutions. In his ethnographic research conducted at two popular educational institutions at the high school level in Palangkaraya, Raihani found that there was discrimination against students who came from weak economies, compared to students who came from strong economies. The majority of economically weak students was classified into the social and language major, which were considered "outcast" major and found it difficult finding a job. Meanwhile, students who came from strong economies were included in the science major who had high prestige and was considered as elected students. ${ }^{25}$

Moreover, the results of Raihani's research suggest that teachers who teach in social and language classes tend to be more lazy and temperamental than teachers who teach in natural science classes. The low motivation of teachers in this social class, of course, has an impact on the low motivation of student learning. ${ }^{26}$ Motivation is a determinant factor for students in achieving learning achievement. More than that, Raihani concluded, that the educational institutions he studied had failed to provide distributive, cultural, and associational justice, and had even perpetuated social injustice. ${ }^{27}$

Case 2 of the large educational institutions that Raihani studied could have happened to the majority of educational institutions in Indonesia. Cultural materialism, which is taken from the positivistic philosophy of the West, which eventually gave birth to a capitalist economic system, inevitably has an impact on our educational institutions. Educational institutions that have strategic prospects in the economic field and power can only be entered by students with high social class, while students in low social classes will only enter vocational educational institutions. It is a form of hegemony in the world of education, as stated by Gramsci. ${ }^{28}$ Apart from Gramsci, Eko Prasetyo also stated that so far the practice of education is still classified as "selective cutting", that is, whoever has good financial quality will get the best education. Money is the most decisive aspect of education. Thus, the world of education is like a market, where students become buyers while teachers and educational institutions become sellers. ${ }^{29}$

${ }^{25}$ Raihani, "Islamic Schools and Social Justice in Indonesia: A Student Perspective," AlJami'ah: Journal of Islamic Studies 50, no. 2 (2012): 286-287.

${ }^{26}$ Nanang Hasan Susanto and Lestari Cindy, "Problematika Pendidikan Islam di Indonesia: Eksplorasi Teori Motivasi Abraham Maslow dan David McClelland,” Edukasia Islamika(2018) 184-202.

${ }^{27}$ Raihani, "Islamic Schools and Social Justice in Indonesia: A Student Perspective." AlJami'ah: Journal of Islamic Studies 50, no. 2 (2012): 294-295.

${ }^{28}$ Antonio Gramsci, Prison Notebook Catatan- Catatan dari Penjara Terjemahan Teguh Wahyu Utomo (Yogyakarta: Pustaka Pelajar): hal 38.

${ }^{29}$ Eko Prasetyo, Guru: Mendidik itu Melawan (Yogyakarta: Resist Book, 2006): 96. 
According to Harker, those phenomenon makes educational institutions or schools a means of reproducing social class positions by some groups. ${ }^{30}$ It is contrary to the vision of the educational institution itself, which carries out the noble task of optimizing all the human potentials of students for the realization of a just life pattern. It is as Topatimasang's criticism says that education should prioritize the process of awareness, enlightenment, empowerment, behavior change, providing learning opportunities, being creative, having the courage to take risks, and asking questions for students. ${ }^{31}$ Because the dichotomy of students, according to Topatimasang, will make the subordinate group remain in the original social class, while the dominant group will remain in the upper society structure. In other words, the advanced groups will be more advanced, and the marginalized groups will be increasingly marginalized and drowned in the increasingly swift currents of globalization to be able to drag into the abyss of poverty.

The Indonesian nation needs the creation of educational institutions that can counteract a culture of materialism to realize the ideals of the nation, namely the realization of the principles of civilized humanity, as well as creating social justice for all Indonesian people through education. Because, as stated in the introduction to this paper, the progress of a nation is very much dependent on the success of that nation in building education. It is also as conveyed by Kholid Musyaddad. ${ }^{32}$

\section{The Concept of Pedagogy for Liberation}

The concept of pedagogy for liberation education was popularized by Paulo Freire, a controversial educational figure who was born on September 19th, 1921 in Recife, to be precise in Northeast Brasilia. ${ }^{33}$ The concept of pedagogy for liberation that Freire adopted originated from the existence of an education system in Brazil which, according to Freire, was not pro-poor, but instead oppressed the weak by the stronger. ${ }^{34}$ Gramsci calls this kind of thing as hegemony, namely cultural leadership run by the ruling class. ${ }^{35}$

${ }^{30}$ Richard Bourdieu Harker, Pendidikan dan Reproduksi Dalam Richard Richard Harker, dkk. (Habitus X Modal) + Ranah = Praktik $:$ Pengantar Paling Komprehensif kepada Pemikiran Pierre Bourdieu. Terjemahan Pipit Meizier (Yogyakarta: Jalasutra, 2009): 127.

${ }^{31}$ Roem Topatimasang, Sekolah Itu Candu (Yogyakarta: InsistPress, 2010): x.

32 Kholid Musyaddad, "Problematika pendidikan di indonesia," EDU_BIO/ Jurnal Pendidikan Biologi 4 (2013): 51.

${ }^{33}$ Denis Colins, Paulo Freire His Life, Works and Thought (New York: Paulist Press, 1977): 5.

${ }^{34}$ Lihat dalam Marthen Manggeng, "Pendidikan Yang Membebaskan Menurut Paulo Freire dan Relevansinya dalam Konteks Indonesia," INTIM: Jurnal Teologi Kontekstual(2005): 41.

35 George Ritzer dan J Goodman, Teori Sosiologi (Yogyakarta: Kreasi Wacana, 2008). Hal 89. 
The education system criticized by Freire is known as "bank style" education, which is education, where students are only a storage container for various formulas and knowledge given by educators and the contents of these containers will be issued when needed. According to Freire, this means that students only memorize what their teacher tells them without understanding it, let alone associate it with social life. ${ }^{36}$ From the education system, Subagi who quoted Martin Sardy as saying that Freire rejected a view that considered humans as passive creatures so that there was no need to make choices about personal responsibility regarding their education. ${ }^{37}$

The rejection of this education system stems from the situation of oppression experienced by Freire when he was a child after Freire's parents who came from the middle class fell into poverty in $1929 .{ }^{38}$ Starting from this experience, Freire proposed a "problem-facing" education system as a substitute for a "bank style" education system. He began to apply the education system when he earned a doctorate then was appointed a professor and served as a lecturer.

The educational system with problems applied by Freire does not show a contradiction between teachers and students. Here teachers and students as subjects who are both learning to face a problem that arises in the reality of life. In this education system, the teacher acts and functions as a coordinator that facilitates dialogical conversations, while students are active participants in the dialogue. ${ }^{39}$ The starting point of this educational system that Freire applies is the man himself because man exists with the world and its reality. The reality must be confronted by students so that they are aware of the realities that exist in life. Such a pedagogical concept is born from the understanding that humans have the potential to create in reality and free themselves from cultural, economic, and even political oppression. ${ }^{40}$ It contrasts with the bank-style education system, which is more directed towards oppressive practices in the world of education. Freire describes these oppressive educational practices by:

a) teachers teach, and students learn

b) the teacher knows everything, while the student knows nothing.

c) the teacher thinks and the student whom the teacher thought.

d) the teacher speaks, and the students listen.

e) the teacher regulates, and the student is regulated.

${ }^{36}$ Paulo Freire, Pendidikan Kaum Tertindas (Jakarta: LP3S, 1972): 50.

${ }^{37}$ Subagi, L, Kritik Atas: Konsientisasi dan Pendidikan. Teropong Paulo Freire dan Ivan Illich, dalam Martin Sardy (ed.), Pendidikan Manusia (Bandung: Alumni, 1985): 104-105.

${ }^{38}$ Sumaryo, Pendidikan Yang Membebaskan dalam Martin Sardy, Mencari Identitas Pendidikan (Bandung: Alumni, 1981): 29.

${ }^{39}$ LihatdalamMarthenManggeng, Op.Cit., p.43

${ }^{40}$ Daniel S Schipani, Religious Education Encounters Liberation Theology (Alabama: Religious Education Press, 1988): 13. 
f) the teacher chooses and enforces his choice, while students must obey.

g) the teacher acts, then the student imagines how to act as the teacher acts.

h) the teacher chooses what to teach, and students adjust accordingly.

i) the teacher confuses the authority of science with the authority of his professionalism, as well as contradicting the way he teaches.

j) the teacher is the subject of the learning process, while the student is the object. $^{41}$

Therefore Freire wanted to liberate the oppressed through the education system against the problems he applied. This liberation is not intended to raise the oppressed to become oppressors, but it is intended to free them from oppression as well as to free the oppressors from oppression. ${ }^{42}$ In this oppressive educational atmosphere, teachers and students alike are alienated from their world. It is where Freire seeks to liberate both the student and the teacher, from this isolation.

\section{The Problems of Contemporary Education}

Based on the description, globalization which unwittingly brings a culture of materialism taken from the philosophy of Western positivity has implications for the formation of the capitalization of education. Capitalization in the world of education seems to be what makes the education system oppressive, as stated by Freire. It is the root of the problem, which is a big problem in the world of education, including in our country.

The world of education is the last bastion in maintaining the cultural identity of a nation. Education is an aspect that greatly determines the journey of a nation. It is as stated by Kholid Musyaddad that a quality human being formed from education is the spearhead of the progress of a nation. Education is also expected to prevent the destruction of a nation as a result of the inability to face the current globalization appropriately. Amir revealed that education should be able to realize a complete human being because education has a function as a process of awareness of humans so that they can recognize, understand, and understand the realities of life that exist. ${ }^{43}$ However, the reality in this life says differently; what we expect about education is not as smooth as imagined, in the educational process, various kinds of problems arise that must be solved.

The changing times that are so fast should ideally be balanced with an educational model that is also fast in responding to it. Various new challenges in

${ }^{41}$ Paulo Freire, Politik Pendidikan: "Kebudayaan, Kekuasaan dan Pembebasan (Yogyakarta: Pustaka Pelajar, 2007): x.

${ }^{42}$ Freire, Pendidikan Kaum Tertindas.(Yogyakarta: Kanisius, 1991): 73

${ }^{43}$ See Amir Rifa'i's introduction, Konsep Pendidikan Pembebasan Mansour Fakih (University of Muhammadiyah Malang, 2013). 
education, such as the increasing interest of modern humans with multifunctional cellphones, require new strategies to deal with them. It is where research is needed in the world of education so that the world of education can answer these challenges. Tilaar has voiced reform in the education system by the times, saying that in facing new challenges that arise it is necessary to use a new strategy as well, if an old strategy is used then all the efforts carried out will fail. ${ }^{44}$

The government has tried to create an education system that is expected to unravel the problems of contemporary education, for example, by creating an Active Student Learning Method system as contained in the 2013 curriculum or by integrating between scientific disciplines which were dichotomous and partial. ${ }^{45}$ However, educational problems cannot be solved automatically.

Students who are not trained to be accustomed to being critical and creative with various problems that arise will make students weak, not independent and not ready to live after leaving an educational institution. It seems to have resulted in the high number of educated unemployment in Indonesia ${ }^{46}$ where many graduates hold a Bachelor's degree, but are not accepted in the job market, or are unable to process the information they receive during school to become creative action.

Many contemporary educational institutions have forgotten the original purpose of education itself, which has been stated in the Law of the Republic of Indonesia Number 20 of 2003 concerning the National Education System chapter 2, article 3 which reads "National education functions to develop capabilities and shape the character and civilization of the nation which having dignity in the framework of developing the intellectual life of the nation, aiming at developing the potential of students to become human beings who believe and fear God Almighty, have a noble character, are healthy, knowledgeable, capable, creative, independent, and become democratic and responsible citizens". ${ }^{47}$

From the editorial of the law, it can be understood that education is intended to develop the abilities or potentials of students, because each of these students

${ }^{44}$ H.A.R. Tilaar, Beberapa Agenda Reformasi Pendidikan Nasional dalam Perspektif Abad 21 (Magelang: Tera Indonesia, 1998): 245.

${ }^{45}$ Miftahur Rohman, Sulthan Syahril, dan Dini Fauziyati, "Masa Depan Studi Islam Di Pendidikan Tinggi Keagamaan Islam (Sebuah Tinjauan Filosofis-Yuridis)," Cendekia: Jurnal Kependidikan Dan Kemasyarakatan 16, no. 2 (22 November 2018): 283.

${ }^{46}$ Based on data ofBadan Pusat Statistik, "Pengangguran Terdidik Indonesia," 15 Maret 2018.jumlah pengangguran terdidik di Indonesia terus meningkat dari tahun ketahun. Pada tahun 2016, jumlah pengangguran terdidik mencapai 7,03 juta orang. Pada tahun 2017, jumlah ini meningkat sebanyak 10.000 orang menjadi 7,04 juta orang. See:https://ekonomi.kompas. com/read/2017/11/06/153940126/agustus-2017-jumlah-pengangguran-naik-menjadi-704-jutaorang

${ }^{47}$ President oftheRepublic of Indonesia, Law of the Republic of Indonesia on the national education system," Pub. L. No. 20, 2 (2003). 
has the potential of each that is different from one another, such as the theory of Multiple Intelligences developed by Howard Gardner. Intelligence is the ability to solve a problem which then produces products through various settings and in real situations, as quoted by Supomo regarding Gardner's definition of intelligence, ${ }^{48}$ this definition is a combination of the three components of multiple intelligences put forward by Gardner.

According to Gardner, the multiple intelligences has three main components as an ability; they are:

1) The ability to solve problems that occur in everyday life.

2) The ability to produce various new problems which are then sought for solutions.

3) The ability to create something or offer a service that will give rise to appreciation in one's culture. ${ }^{49}$

Contemporary education is more concerned with results than processes, it can be said that what is the goal of contemporary education is to create learners who are rich in knowledge through materials or formulas that have become benchmarks from the government for provision for their future, but this will make participants students are depressed and feel they are not given freedom in education, they are required to get good results without paying attention to how the process is, therefore nowadays there are many educated unemployed as a result of the inability to face problems that arise in the reality of life.

\section{Unravelling the Problems of the World of Contemporary Education Based on Pedagogy for Liberation}

Contemporary education that does not give freedom to students is a problem that must be resolved immediately by finding the right solution. The National Education System Law mandates educational institutions to organize a community-based education system. ${ }^{50}$ This education system can be used as a guide for solving problems that arise in contemporary educational institutions. The spirit to be conveyed in education based on and integrated with people's lives or known as grass root people ${ }^{51}$ education must be read as an effort to

${ }^{48}$ Paul Suparno, Teori Inteligensi Ganda dan Aplikasinya di Sekolah (Yogyakarta: Kanisius, 2004): 17.

${ }^{49}$ Howard Gardner, Multiple Intelligences : The Theory in Practice A Reader (New York: Basic Books, 1993): x.

${ }^{50}$ Community-based education is the provision of education based on the uniqueness of religion, social, culture, aspirations and potential of the community as a manifestation of education from, by, and for the community (seePresident oftheRepublic of Indonesia, Law of the Republic of Indonesia on the national education system. Page 2.

${ }^{51}$ Ahmad Royani, "Eksistensi Pendidikan Pesantren dalam Arus Perubahan," Cendekia: Jurnal Kependidikan Dan Kemasyarakatan 16, no. 2 (22 November 2018): 375. 
maintain the identity of a nation while remaining open to the times. However, at the level of reality, this education system has not been able to answer the problems that arise in contemporary educational institutions.

Based on the author's analysis, the unanswered problems caused by the presentation given to students is still rigid and is legal and formal. Students are too required to be perfect according to the measure of perfection that has been determined by the curriculum and textbooks. It will make students fixated on the results they have to get and do not care about the process. A large number of subjects in schools with their respective curriculum is also a problem in implementing community-based education. Instead of providing meaningful education, by linking the subject matter to the concrete social realities faced by everyday students, ${ }^{52}$ our teachers often complain that time is running out to complete subject matter even though it is only limited to cognitive knowledge. What happens then is chasing the target of delivering the material, by taking into account the comfort and ability of students in receiving lessons, let alone linking the subject matter with everyday life.

The concept of pedagogy for liberation as conveyed by Freire, according to the author, can be used as an alternative solution in parsing the problems of National education in the form of the erosion of cultural identity and the increasing capitalization of education as described. Education must be used as an effort to liberate humans. According to Freire, education must be returned to its function as a tool to free humans from various forms of oppression and oppression, or it can be called an effort to humanize humans (humanization). ${ }^{53}$ Through the principle of pedagogy for liberation, students are given the freedom not only about learning models that are fun ${ }^{54}$ and provide comfort in learning, but also to develop all their potential so that students become free and independent physically, mentally, and spiritually, and not only develop in the intellectual aspect only. ${ }^{55}$

Ideally, pedagogy for liberation is not trapped in the search for individual freedom alone but has a vision of realizing social humanization. It is also as expressed by Habermas, who voiced the importance of eliminating all forms of

${ }^{52}$ Dadan Rosana, "Model Pembelajaran Lima Domain Sains dengan Pendekatan Kontekstual untuk Mengembangkan Pembelajaran Bermakna," Jurnal Penelitian dan Evaluasi Pendidikan 13, no. 2: 2009: 276.

${ }^{53}$ Freire, Pendidikan Kaum Tertindas.

${ }^{54}$ An explanation of the importance of providing a pleasant education can be read in Failasuf Fadli and Nanang Hasan Susanto, "Model Pendidikan Islam Kreatif Walisongo, Melalui Penyelenggaraan Pendidikan Yang Menyenangkan," Jurnal Penelitian 11, no. 1 (2017): 52.

${ }^{55}$ Erna Nurkholida, "FILSAFAT PENDIDIKAN MENURUT PERSPEKTIF JAWA (Studi Pemikiran Ki Hajar Dewantara)," Cendekia: Jurnal Kependidikan Dan Kemasyarakatan 16, no. 2 (22 November 2018): 393. 
oppression, through freedom of opinion, or what is known as "argumentation", which is a situation that places participants in communication who can critically examine a hypothetical validity. ${ }^{56}$ Thus, the notion of freedom in pedagogy for liberation is an attempt to humanize humans. As stated by Freire and Ilich, all education that is oriented towards human humanity can be said to be an education that is liberating. Therefore, the most basic thing in liberation education is education that humanizes humans. ${ }^{57}$

Through the principle of pedagogy for liberation, teachers are no longer trapped in fulfilling a rigid curriculum (to borrow Freire's term: bank style education), but more time is devoted to analyzing the social realities faced by students, to then design the subject matter needed to face and answer various problems and challenges from these social realities (to borrow Freire's term: problem-facing). Thus, the challenges of globalization, in the form of the erosion of cultural identity, can be unravelled through the pedagogy for liberation model.

The implementation of pedagogy for liberation is also expected to be able to build awareness or critical attitude of students so that they can solve any problems that arise in the realities of life, and are free from all forms of colonialism. ${ }^{58}$ With this critical attitude, a group of enlightened students is expected to be able to have class consciousness, so that they can do something tangible for the realization of social justice, and eliminate or at least minimize the occurrence of various forms of oppression. It is where the big problem of our education, which Darmaningtyas calls the capitalization of education, is expected to be resolved through pedagogy for liberation.

\section{CONCLUSION}

Globalization has unwittingly brought a culture of materialism that is rooted in the philosophy of Western positivity, which has implications for the erosion of cultural identity and the rampant capitalization of education. It is a big problem in national education. To solve this problem, educational institutions that can transmit the concept of freeing Freire's education are needed, namely critical education to dismantle hegemonic relations from dominant state culture to developing country culture, as well as education based on problem-solving.

Today's education is too preoccupied with something artificial, preoccupied with textbooks and curricula that are not in touch with social reality so that

${ }^{56}$ Jürgen Habermas, Moral Consciousness and Communicative Action (ori: 1983, 'Moralbewusstsein und kommunikativen Handeln', transl by Christian Lenhart \& Shierry Weber Nicholson, introduction by Thomas McCharty) (Cambridge: Polity Pres, 1990): 85.

${ }^{57}$ Paulo Freire dan Ivan Illich, Menggugat Pendidikan (Yogyakarta: Pustaka Pelajar, 2009): 446.

${ }^{58}$ Nanang Hasan Susanto, "Kontekstualisasi Pendidikan Kritis Berbasis Pemikiran Ali Syari'ati di Indonesia," Journal of Islamic Studies and Humanities 3, no. 1 (2019): 1-20. 
328 Nanang Hasan Susanto dkk, Cultural Identity

education often becomes both burdensome and at the same time kills the creativity of students. Through the principle of liberating education, students are given freedom not only about learning models that are fun and provide comfort in learning, but also to develop all the potential that students have. 


\section{REFERENCES}

Adian, Donny Gahral. "Reasoning in A Multicultural Society." Wacana 13, no. 2 (2011): 360 .

Badan Pusat Statistik. "Pengangguran Terdidik Indonesia," 15 Maret 2018.

Colins, Denis. Paulo Freire His Life, Works and Thought. New York: Paulist Press, 1977.

Darmaningtyas. Pendidikan Rusak-Rusakan. Yogyakarta: LkiS, 2009.

Fadli, Failasuf, andNanang Hasan Susanto. "Model Pendidikan Islam Kreatif Walisongo, Melalui Penyelenggaraan Pendidikan Yang Menyenangkan.” Jurnal Penelitian 11, no. 1 (2017).

Fakih, Mansour. Runtuhnya Teori Pembangunan dan Globalisasi. Yogyakarta: Pustaka Pelajar, 2002.

Freire, Paulo. Pendidikan Kaum Tertindas. Jakarta: LP3S, 1972.

_. Politik Pendidikan: "Kebudayaan, Kekuasaan dan Pembebasan. Yogyakarta: Pustaka Pelajar, 2007.

Freire, Paulo, and Ivan Illich. Menggugat Pendidikan. Yogyakarta: Pustaka Pelajar, 2009.

Gardner, Howard. Multiple Intelligences: The Theory in Practice A Reader. New York: Basic Books, 1993.

Geertz, Clifford. Politik Kebudayaan. Yogyakarta: Kanisius, 1992.

Gramsci, Antonio. Prison Notebook Catatan- Catatan dari Penjara Terjemahan Teguh Wahyu Utomo. Yogyakarta: Pustaka Pelajar, t.t.

Habermas, Jürgen. Moral Consciousness and Communicative Action (asli: 1983, 'Moralbewusstsein und kommunikativen Handeln', transl by Christian Lenhart \& Shierry Weber Nicholson, introduction by Thomas McCharty). Cambridge: Polity Pres, 1990.

Hall, Stuart. "Cultural Identity and Cinematic Representation." Framework: The Journal of Cinema and Media 36 (1989): 68-81. 
Harker, Richard Bourdieu. Pendidikan dan Reproduksi Dalam Richard Richard Harker, dkk. (Habitus X Modal) + Ranah = Praktik $:$ Pengantar Paling Komprehensif kepada Pemikiran Pierre Bourdieu. Terjemahan Pipit Meizier. Yogyakarta: Jalasutra, 2009.

Koentjaraningrat. Manusia dan Kebudayaan di Indonesia. Jakarta: Djambatan, 1983.

Levine, George. "Speaking for the Humanities." American Council of Learned Societies Occasional Paper, no. 7 (1989).

Manggeng, Marthen. "Pendidikan Yang Membebaskan Menurut Paulo Freire dan Relevansinya dalam Konteks Indonesia." INTIM: Jurnal Teologi Kontekstual, 2005.

Mubah, A. Safril. "Strategi Meningkatkan Daya Tahan Budaya Lokal dalam Menghadapi Arus Globalisasi." Jurnal Unair 24, no. 4 (t.t.): 2011.

Musyaddad, Kholid. "Problematika pendidikan di indonesia." EDU_BIO/ Jurnal Pendidikan Biologi 4 (2013).

Nurkholida, Erna. "Filsafat Pendidikan Menurut Perspektif Jawa (Studi Pemikiran Ki Hajar Dewantara)." Cendekia: Jurnal Kependidikan Dan Kemasyarakatan 16, no. 2 (22 November 2018): 393.

Perrot, Etienne. The General Dimension of Globalization and Its Critics: The Ambiguitas of Globalization dalam Concilium. London: SCM Press, 2001.

Piliang, Yasraf Amir. Kode, Gaya dan Matinya Makna: Semiotika dan Hipersemiotika. Bandung: Matahari, 2010.

Prasetyo, Eko. Guru: Mendidik itu Melawan. Yogyakarta: Resist Book, 2006.

Presiden Republik Indonesia. Undang-undang Republik Indonesia tentang sistem pendidikan nasional, Pub. L. No. 20, 2 (2003).

Putra, Heddy Shri Ahimsa. "Kebhinnekaan Budaya sebagai Modal Merespons Globalisasi." LITERASI: Indonesian Journal of Humanities 4, no. 2 (2015).

Raihani. "Islamic Schools and Sosial Justice in Indonesia: A Student Perspective." Al-Jami'ah: Journal of Islamic Studies 50, no. 2 (t.t.): 2012.

Rifa'i, Amir. Konsep Pendidikan Pembebasan Mansour Fakih. University of Muhammadiyah Malang, 2013. 
Ritzer, George, dan J Goodman. Teori Sosiologi. Yogyakarta: Kreasi Wacana, 2008.

Rohman, Miftahur, Sulthan Syahril, dan Dini Fauziyati. "Masa Depan Studi Islam Di Pendidikan Tinggi Keagamaan Islam (Sebuah Tinjauan FilosofisYuridis)." Cendekia: Jurnal Kependidikan Dan Kemasyarakatan 16, no. 2 (22 November 2018): 283.

Rosana, Dadan. "Model Pembelajaran Lima Domain Sains dengan Pendekatan Kontekstual untuk Mengembangkan Pembelajaran Bermakna.” Jurnal Penelitian dan Evaluasi Pendidikan 13, no. 2 (t.t.): 2009.

Roxborough, Ian. Teori-teori Keterbelakangan. Jakarta: LP3ES, 1986.

Royani, Ahmad. "Eksistensi Pendidikan Pesantren dalam Arus Perubahan." Cendekia: Jurnal Kependidikan Dan Kemasyarakatan 16, no. 2 (22 November 2018): 375.

Rujito, Eko. "Boneka Barbie: antara Etos Kemandirian dan Budaya Materialisme." Majalah Ilmiah Pembelajaran 8, no. 2 (t.t.).

Sahlins, Marshall. Goodbye to Tristes Tropique: Ethnography in the Context of Modern World History, dalam R.Borofsky, (ed.) Assessing Cultural Anthropology. New York: McGraw-Hill Inc, 1994.

Said, Edward. Orientalisme. Bandung: Pustaka, 1994.

Schipani, Daniel S. Religious Education Encounters Liberation Theology. Alabama: Religious Education Press, 1988.

Subagi, L. Kritik Atas: Konsientisasi dan Pendidikan. Teropong Paulo Freire dan Ivan Illich, dalam Martin Sardy (ed.), Pendidikan Manusia. Bandung: Alumni, 1985.

Sudarsana, I. Ketut. "Pemikiran tokoh pendidikan dalam buku lifelong learning: policies, practices, and programs (Perspektif Peningkatan Mutu Pendidikan di Indonesia)." Jurnal Penjaminan Mutu 2, no. 2 (2016).

Sumaryo. Pendidikan Yang Membebaskan dalam Martin Sardy, Mencari Identitas Pendidikan. Bandung: Alumni, 1981.

Suneki, Sri. "Dampak Globalisasi terhadap Eksistensi Budaya Daerah.” Jurnal Ilmiah CIVIS 2, no. 1 (2012). 
Sunhaji. "Between Sosial Humanism And Sosial Mobilization: The Dual Role of Madrasah in the Landscape of Indonesian Islamic Education." Journal Of Indonesian Islam 11, no. 1 (2017): 125-44.

Suparno, Paul. Teori Inteligensi Ganda dan Aplikasinya di Sekolah. Yogyakarta: Kanisius, 2004.

Supriyoko, Ki. "Sistem Pendidkan Nasional dan Peran Budaya Dalam Pembangunan Berkelanjutan.” Denpasar, 2003.

Suradi, Ahmad. "The Challenges of Education Based on Multicultural in National Local Culture Conservation in Globalization Era." Cendekia: Jurnal Kependidikan Dan Kemasyarakatan 16.1 (2018): 103-124..

Susanto, Nanang Hasan. "Infiltrasi Globalisasi Terhadap Identitas Budaya dan Pendidikan Karakter Negara Berkembang." Lembaran Ilmu Kependidikan 47, no. 2 (2018): 57-66.

—_. "Kontekstualisasi Pendidikan Kritis Berbasis Pemikiran Ali Syari'ati di Indonesia." Journal of Islamic Studies and Humanities 3, no. 1 (2019): 1-20.

Susanto, Nanang Hasan, and Lestari Cindy. "Problematika Pendidikan Islam di Indonesia: Eksplorasi Teori Motivasi Abraham Maslow dan David McClelland.” Edukasia Islamika, 2018, 184-202.

Sztompka, Piotr. Sosiologi Perubahan Sosial. Terj. Alimandan dari "The Sociology of Sosial Change.” Jakarta: Prenada, 2004.

Tilaar, H.A.R. Beberapa Agenda Reformasi Pendidikan Nasional dalam Perspektif Abad 21. Magelang: Tera Indonesia, 1998.

Topatimasang, Roem. Sekolah Itu Candu. Yogyakarta: InsistPress, 2010. 